\title{
Protective effect and mechanism of estrogen receptor $\beta$ on myocardial infarction in mice
}

\author{
JUN-BIAO ZHANG and CHANG-LEI GUO
}

\author{
Department of Cardiovascular Internal Medicine, The First Affiliated Hospital \\ of Xinxiang Medical University, Weihui, Henan 453100, P.R. China
}

Received September 19, 2016; Accepted March 10, 2017

DOI: $10.3892 /$ etm.2017.4628

\begin{abstract}
The protective effect and the mechanism of estrogen receptor $\beta(E R \beta)$ on myocardial infarction $(\mathrm{MI})$ in mice were explored. A total of 12 female $\mathrm{Tg}-\mathrm{ER} \beta$ transgenic mice and 12 non-transgenic littermate control (NLC) wild-type C57 mice were used for the present study. Both transgenic and wild-type mice had similar baseline data such as age, sex, and weight. The mouse model of MI was established by coronary artery ligation method, and the cardiac structure and function changes of the mouse were observed by ultrasonic echocardiography on days 1, 3 and 7 after the operation. RT-PCR method was used to detect the expression of collagen I, $\alpha$-SMA, TGF- $\beta$ mRNA in the mouse heart, and Masson staining was used to detect cardiac fibrosis. At 3 days after operation, echocardiographic posterior wall thickness at end diastole (PWTD) and end systolic PWTS of Tg-ER $\beta$ mice were significantly reduced, and left ventricular systolic diameter and left ventricular diastolic diameter significantly increased $(\mathrm{P}<0.05)$ compared with NLC mice. The levels of expression of Tg-ER $\beta$ cardiac tissue collagen I, $\alpha$-SMA, TGF- $\beta$ mRNA were significantly lower than those in the NLC mice $(\mathrm{P}<0.05)$. In conclusion, $\mathrm{Tg}$-ER $\beta$ exerts a protective effect on MI.
\end{abstract}

\section{Introduction}

Myocardial infarction (MI) adversely affects major killers of human health. Acute MI is caused by acute persistent ischemia and hypoxia (1). The clinical manifestations are severe and persistent retrosternal pain. Rest and nitrate cannot completely achieve remission, accompanied by serum

Correspondence to: Dr Jun-Biao Zhang, Department of Cardiovascular Internal Medicine, The First Affiliated Hospital of Xinxiang Medical University, 88 Jiankang Road, Weihui, Henan 453100, P.R. China

E-mail: pwcp_331639@163.com

Key words: estrogen receptor $\beta$, myocardial infarction, echocardiographic, posterior wall thickness at end diastole, left ventricular diastolic diameter myocardial enzyme spectrum changes. Changes in electrocardiogram, arrhythmia, shock or heart failure risk increase, and become life-threatening (2,3). Approximately 1.5 million individuals in the United States have MI each year $(4,5)$. In China, with the development of economy and the improvement of living standards, the annual new onset is $\geq 0.5$ to 2 million individuals. Although early MI can achieve good therapeutic effect through intervention and drug treatment with the improvement of the level of medical technology, MI early warning to prevent the occurrence of MI remains, however, the current research hotspot (6-8).

Estrogen receptor $\beta(\mathrm{ER} \beta)$ genes, encoding $\mathrm{ER} \beta$ plays an important role in the regulation of normal physiology, aging and many diseases (9). The most classical function of ER is described as a ligand activated transcription factor, which can mediate gene transcription in tissues and organs regulated by hormones (10). ER $\beta$ is usually highly expressed in breast cancer, prostate cancer and other tumors, and may change with the menstrual cycle. Clinical studies have indicated that the level of expression of ER $\alpha$ is closely related to the degree of differentiation of breast cancer cells and their degree of malignancy (11-14). In MI, ER $\beta$ increase cardiac function in patients with acute MI by modulating the PI3K/Akt signaling pathway (15). In addition, ER $\beta$ can improve myocardial fibrosis after MI (16).

On the basis of previous research, we investigated the role of ER $\beta$ in left ventricular remodeling in mice after $\mathrm{MI}$ in order to understand the mechanism and provide theoretical basis for MI and fibrosis therapy, as well as the targets for drug development.

\section{Materials and methods}

Experimental animals. The use of experimental animals in this study was approved by the ethics committee of our university. The general characteristics of Tg-ER $\beta$ have been reported in previous literature (8). Microinjection DNA box sequence to the C57BL/6 mouse fertilized oocytes were implanted into pseudopregnant mice. The injection of sequence contained the cDNA ORF region of ERB gene in the mice, and was regulated by $\alpha$-myosin heavy chain promoter.

Non-transgenic littermate control (NLC) mice were C57BL/6 mice that did not receive the microinjection (for the microinjection of the mouse brothers and sisters) in 
order to ensure the genetic background to be similar to Tg-ER $\beta$ mice.

Grouping. NLC mice were divided into the transgenic group and the control group. Each group had 12 mice, the average body weight was $23.9 \pm 3.6 \mathrm{~g}$, and the average age was $3.1 \pm 0.3$ weeks. Coronary artery ligation (CAL) was used to construct a mouse model of MI in mice randomly selected from each group $(n=6)$. Cardiac structure and function changes were observed in the mice 1, 3 and 7 days after surgery, respectively. RT-PCR method was used to detect the expression of collagen I, $\alpha$-SMA, TGF- $\beta$ mRNA in the mouse heart, and Masson staining was used to detect cardiac fibrosis.

Instrument. Biological safety cabinet (Esco Micro Pte., Ltd., Singapore, Republic of Singapore), PCR amplification instrument (Eppendorf AG, Hamburg, Germany), gel imaging instrument (Syngene, Frederick, MD, USA), electrophoresis apparatus (Beijing 61 Instrument Factory, Beijing, China), centrifuge (Eppendorf AG), micropipet (Eppendorf AG), Haier ice machine, western blot electrophoresis apparatus trophoresis (Bio-Rad Laboratories, Hercules, CA, USA), $-80^{\circ} \mathrm{C}$ refrigerator (Thermo Fisher Scientific, Waltham, MA, USA), $10 \mathrm{ml}$ syringe, $5 \mathrm{ml}$ syringe (Tianjin Hanaco Medical Co., Ltd., Tianjin, China), experimental animal surgical instruments (Beijing Medical Equipment Factory, Beijing, China), NanoDrop2000 photometric analyzer (Thermo Fisher Scientific), EP tube (Eppendorf AG), water bath (Beijing Medical Equipment Factory), and pathological section machine (Leica, Mannheim, Germany) were used in the present study.

Reagent. Taq Master Mix (SinoBio, Shanghai, China), agarose (Biowest, Nuaille, France), sterile double distilled water, sterile double distilled water, monoclonal rabbit $\beta$-actin antibody (dilution, 1:5,000; cat. no. MA5-15739; Invitrogen Life Technologies, Carlsbad, CA, USA), polyclonal rabbit ER $\beta$ antibody (dilution, 1:500; cat. no. BD-PT1637; BioLegend, Inc., San Diego, CA, USA), monoclonal rabbit phosphorylation ER $\beta$ antibody (dilution, 1:1,000; cat. no. orb10614; Cell Signaling Technology, Inc., Danvers, MA, USA), $0.9 \%$ stroke-physiological saline solution (Otsuka Pharmaceutical Co., Ltd., Tokyo, Japan), pentobarbital sodium (Guangzhou Chemical Reagent Factory, Guangzhou, China), TRIzol (Invitrogen Life Technologies), AngII (RayBiotech, Norcross, GA, USA), and acetic acid (Guangzhou Chemical Reagent Factory) constituted the reagents used in this study. Phosphate buffer was purchased from Gibco Life Technologies (Carlsbad, CA, USA).

\section{Method}

Ligation of coronary artery. The procedure followed for ligation of coronary artery (8) was: i) Preoperative preparation: The artery was fixed by phenobarbital anesthesia, tracheal incision intubation was undertaken after successful intubation under the use of ventilation. ii) The skin was cut; muscles were separated in the 4th intercostal level to get into the chest. After good exposure of the heart, the left coronary artery was separated. The 6-0 non-destructive suture ligation was used. iii) After the ligation, the heart was returned to the chest, and the incision skin was sutured.

Small animal ultrasound. The small animal ultrasound (9) was used to evaluate the diastolic (PWTD), end systolic (PWTS), left ventricular systolic diameter (LVESD) and left ventricular diastolic diameter (LVEDD). Mice were anesthetized by isoflurane and then tested before ultrasound examination.

Detection of levels of collagen I, $\alpha-S M A$, and TGF- $\beta$. RT-PCR assay was used to detect the levels of collagen I, $\alpha$-SMA, and TGF- $\beta$ (10-12). The tissue samples obtained in the first step were used to extract the RNA in the tissue by TRIzol method (Invitrogen Life Technologies). After the extraction, NanoDrop2000 photometric analyzer (Thermo Fisher Scientific) was used to measure the concentration 260/280. Under normal circumstances, OD260/280 of RNA was in the range of 1.7-2.0, if $<1.7$, it suggested that there might be protein or phenol pollution, if $>2.0$, it suggested that there was acid residue, that needed further extraction for the detection of purity.

Immunohistochemistry. Prior to immuno-histochemistrystaining, the paraffin section of rat brain was first prepared, including fixation, dehydration, transparency, embedding, slice, patch and so on. After the paraffin section was prepared, the immunofluorescent staining was performed as follows: At $20^{\circ} \mathrm{C}$, the section was placed still for $60 \mathrm{~min}$, and then was immersed by xylene for $25 \mathrm{~min}$. The section was immersed by anhydrous alcohol for $2 \mathrm{~min}$, and by 95 , 80 and $70 \%$ alcohol, each for $2 \mathrm{~min}$, then was washed by PBS 2-3 times for $5 \mathrm{~min}$. The section was incubated with $3 \% \mathrm{H}_{2} \mathrm{O}_{2}$ deionized water for $10 \mathrm{~min}$ and washed by PBS for 2-3 times for $5 \mathrm{~min}$. The section was boiled in citrate buffer ( $\mathrm{pH} 6.0$ ) at $95^{\circ} \mathrm{C}$ for $15-20 \mathrm{~min}$ and cooled to room temperature with cold water, and then was washed by PBS for 2-3 times for $5 \mathrm{~min}$. The section was incubated with normal goat serum blocking solution at room temperature for $20 \mathrm{~min}$, and excess solution was discarded. The section was incubated with primary polyclonal rabbit ER $\beta$ antibody (dilution, 1:500; cat. no. BD-PT1637; BioLegend, Inc.) at room temperature for $1 \mathrm{~h}$ and then washed with PBS for 2-3 times for $5 \mathrm{~min}$. The section was incubated with secondary goat anti-rabbit (HRP) IgG antibody (dilution, 1:2,000; cat. no. ab6721) at room temperature for $1 \mathrm{~h}$ and then washed with PBS for 2-3 times for $5 \mathrm{~min}$. The section was incubated with streptavidin peroxidase at room temperature for $30 \mathrm{~min}$ and then washed with PBS for 2-3 times for $5 \mathrm{~min}$. DAB visualization was performed for 5-10 $\mathrm{min}$. Under a microscope, those cells with brown cytoplasm were judged as positive cells. Tap water washing was performed for $10 \mathrm{~min}$ to stop the reaction. Hematoxylin staining was performed for $2 \mathrm{~min}$, and hydrochloric alcohol differentiation was performed; The section was washed by tap water for $10 \mathrm{~min}$ and then was dehydrated, cleared and mounted. Neutral latex was added, and the coverslip was covered before microscopic examination. Immunohistochemical staining results were analyzed using Image-Pro Plus 6.0 (version X; Media Cybernetics, Silver Springs, MD, USA). 
A

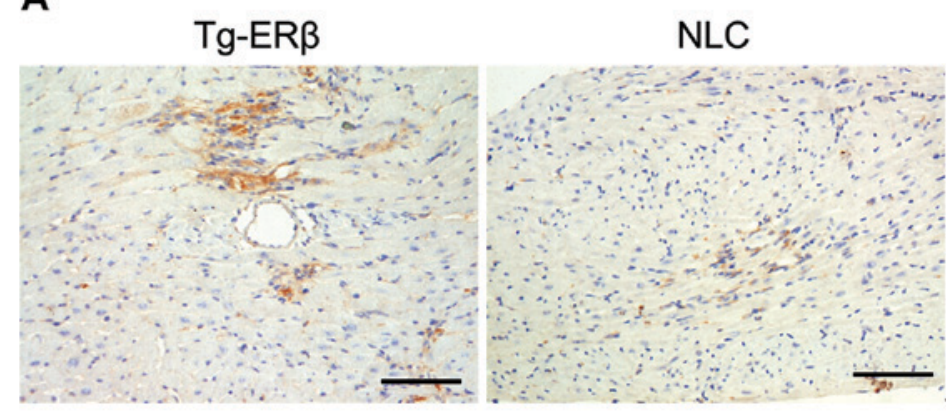

B

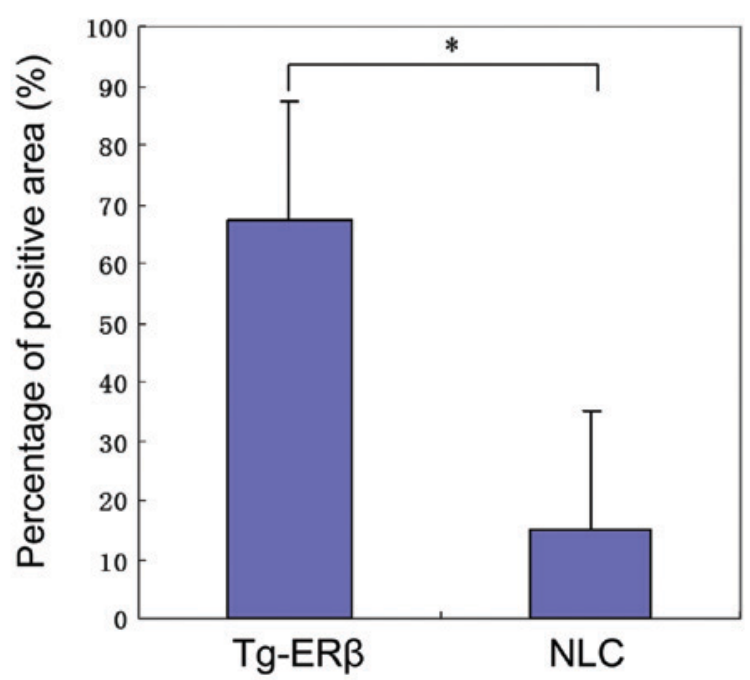

Figure 1. Immunohistochemical staining of ER $\beta$. (A) Magnification of x400 showing myocardial interstitials. Image-Pro Plus6.0 software was used for statistics of expression of regional myocardial tissue ER $\beta$ of mice, and the results are shown. (B) Immunohistochemical staining shows that there was slight expression of ER $\beta$ in the myocardium of NLC mice, the expression of ER $\beta$ in Tg-ER $\beta$ group was significantly higher than that in NLC mice, and the difference was statistically significant $\left({ }^{*} \mathrm{P}<0.05\right)$. The model of transgenic mice was successfully established. ER $\beta$, estrogen receptor $\beta$; NLC, non-transgenic littermate control.

Masson staining. Paraffin sections were dewaxed in water prior to washing by tap water and distilled water in turn. We used Regaud hematoxylin stain or Weigert staining sperm nuclear for 5-10 min. If necessary, hydrochloric acid alcohol differentiation was washed by distilled water. The Masson acid complex red blood staining of myocardial tissue was for 5-10 min as previously described (14). We used 2\% acetic acid aqueous solution soaking for $10 \mathrm{~min}$ and $1 \%$ phosphomolybdic acid aqueous solution of differentiation for 3-5 min. We directly used aniline blue or light green liquid dye for $5 \mathrm{~min}$. We used $0.2 \%$ acetic acid aqueous solution soaking and sealed with $95 \%$ alcohol, anhydrous alcohol and xylene transparent neutral gum. Collagen fibers, mucus, and cartilage were blue, cytoplasm, muscle, cellulose and glial were red, and the nucleus was black blue.

Statistical analysis. Statistical analysis was performed with SPSS 19.0 (SPSS, Inc., Chicago, IL, USA). Analysis of variance (ANOVA) and $\chi^{2}$ test were used to analyze the normal distribution data. Fisher's exact probability method was used for the data of the four cases that did not satisfy the condition. The comparison of skewed distribution data was tested by paired t-test or $\chi^{2} . \mathrm{P}<0.05$ was considered to indicate a statistically significant difference.

\section{Results}

Expression of ER $\beta$ before and after CAL. In order to detect the expression of $E R \beta$ in the groups before and after CAL, one randomly selected mouse was sacrificed it in the transgenic and the control group, respectively, and then cardiac ER $\beta$ was stained. There was slight expression of ER $\beta$ in the myocardium of NLC mice, and the difference was statistically significant compared with that of the transgenic mice $(\mathrm{P}>0.05)$. The expression of ER $\beta$ in the Tg-ER $\beta$ group was significantly higher than that in NLC mice $(\mathrm{P}<0.05)$. After AngII reperfusion, there was a trend of increase of $\operatorname{ER} \beta$ expression in Tg-ER $\beta$ (P>0.05; Fig. 1).

Mouse cardiac ultrasound index after construction of MI model. In order to observe the cardiac function of the two groups of mice after MI, we performed echocardiography. As compared with the NLC mice, end echocardiographic diastolic PWTD and end systolic PWTS of Tg-ER $\beta$ mice were significantly reduced $(\mathrm{P}<0.05)$. By contrast, end systolic LVESD and end echocardiographic diastolic LVEDD were also significantly increased in Tg-ER $\beta$ mice $(\mathrm{P}<0.05)$. Ejection fraction $(\mathrm{EF} \%)$ and short axis shortening rate (FS\%) decreased significantly in $\mathrm{Tg}$-ER $\beta$ mice $(\mathrm{P}<0.05)$. In addition, 7 days 
Table I. Statistics of echocardiography (mean \pm standard deviation).

\begin{tabular}{|c|c|c|c|c|}
\hline Characteristics & NLC & $\mathrm{NLC}+\mathrm{CAL}$ & $\operatorname{Tg}-\mathrm{ER} \beta$ & $\mathrm{Tg}-\mathrm{ER} \beta+\mathrm{CAL}$ \\
\hline No. & 5 & 6 & 5 & 6 \\
\hline BW (g) & $22.7 \pm 2.2$ & $24.2 \pm 1.2$ & $24.8 \pm 1.2$ & $23.8 \pm 1.3$ \\
\hline HR (bmp) & $412.3 \pm 27.7$ & $431.4 \pm 11.9$ & $466.8 \pm 28.7$ & $428.4 \pm 19.6$ \\
\hline $\operatorname{PWTD}(\mathrm{mm})^{\mathrm{a}}$ & $1.17 \pm 0.48$ & $0.71 \pm 0.21$ & $0.83 \pm 1.24$ & $0.67 \pm 0.21$ \\
\hline $\operatorname{PWTS}(\mathrm{mm})^{\mathrm{a}}$ & $1.61 \pm 0.14$ & $1.24 \pm 0.21$ & $1.42 \pm 0.32$ & $1.20 \pm 0.45$ \\
\hline $\operatorname{AWTD}(\mathrm{mm})^{\mathrm{a}}$ & $0.85 \pm 0.12$ & $0.72 \pm 0.02$ & $0.87 \pm 0.03$ & $0.70 \pm 0.11$ \\
\hline $\operatorname{AWTS}(\mathrm{mm})^{\mathrm{a}, \mathrm{b}}$ & $1.71 \pm 0.13$ & $1.31 \pm 0.12$ & $1.48 \pm 0.17$ & $1.28 \pm 0.21$ \\
\hline $\operatorname{LVEDD}(\mathrm{mm})^{\mathrm{a}}$ & $3.03 \pm 0.44$ & $3.98 \pm 0.24$ & $3.52 \pm 0.26$ & $3.88 \pm 0.31$ \\
\hline $\operatorname{LVESD}(\mathrm{mm})^{\mathrm{a}, \mathrm{b}}$ & $1.59 \pm 0.32$ & $2.49 \pm 0.31$ & $2.16 \pm 0.47$ & $2.41 \pm 0.13$ \\
\hline $\mathrm{CO}(\mathrm{ml} / \mathrm{min})^{\mathrm{a}, \mathrm{b}}$ & $15.93 \pm 5.85$ & $18.19 \pm 2.43$ & $17.25 \pm 4.38$ & $18.20 \pm 3.24$ \\
\hline $\mathrm{FS}(\%)^{\mathrm{a}, \mathrm{b}}$ & $58.24 \pm 2.43$ & $37.24 \pm 2.19$ & $37.10 \pm 1.28$ & $42.36 \pm 1.25$ \\
\hline $\mathrm{EF}(\%)^{\mathrm{a}, \mathrm{b}}$ & $81.95 \pm 2.16$ & $67.81 \pm 1.33$ & $67.42 \pm 1.05$ & $73.22 \pm 1.48$ \\
\hline LV mass (AW) corrected ${ }^{\mathrm{a}, \mathrm{b}}$ & $83.29 \pm 11.47$ & $82.44 \pm 10.96$ & $84.34 \pm 10.52$ & $86.93 \pm 13.82$ \\
\hline
\end{tabular}

${ }^{\mathrm{a}} \mathrm{P}<0.05,{ }^{\mathrm{b}} \mathrm{Tg}$-ER $\beta$ was compared with NLC and the differences had statistical significance. NLC, non-transgenic littermate control; ER $\beta$, estrogen receptor $\beta$; CAL, coronary artery ligation; BW, body weight; PWTD, posterior wall thickness at end diastole; PWTS, posterior wall thickness at end systolic; AWTD, anterior wall thickness at end diastole; AWTS, anterior wall thickness at end systolic; LVEDD, left ventricular diastolic diameter; LVESD, left ventricular systolic diameter; FS, fractional shortening; EF, ejection fraction; LV, left ventricular.

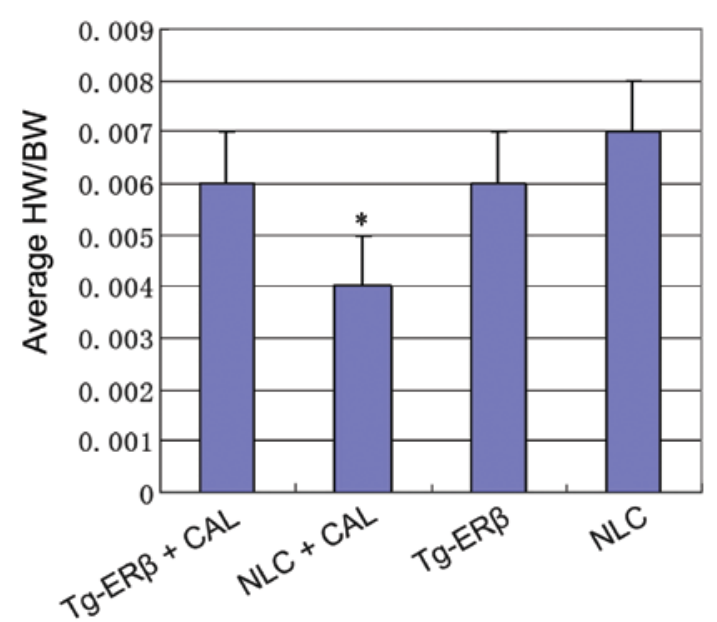

Figure 2. Compared with the Tg-ER $\beta$ group, the average HW/BW of the NLC group was significantly decreased, and the difference was statistically significant $\left({ }^{*} \mathrm{P}<0.05\right)$. ER $\beta$, estrogen receptor $\beta$; NLC, non-transgenic littermate control; CAL, coronary artery ligation; HW/BW, heart weight to body weight.

after MI, end echocardiographic diastolic PWTD and end systolic PWTS were significantly increased in Tg-ER $\beta$ mice $(\mathrm{P}<0.05)$. Furthermore, end systolic LVESD and end echocardiographic diastolic LVEDD were significantly higher in NLC mice than those of Tg-ER $\beta$ mice $(\mathrm{P}<0.05)$. However, compared with the NLC mice, end echocardiographic diastolic PWTD and end systolic PWTS of Tg-ER $\beta$ mice were significantly reduced $(\mathrm{P}<0.05)$, whereas the end systolic LVESD and end echocardiographic diastolic LVEDD were also significantly increased $(\mathrm{P}<0.05)$ in Tg-ER $\beta$ mice, suggesting the protecting ventricular remodeling effect of Tg-ER $\beta$ after MI (Table I).

Heart weight ratio test. To study the absolute changes in the weight of the heart of the mouse, we measured the heart
A

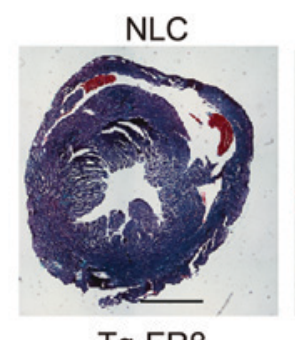

$\mathrm{NLC}+\mathrm{CAL}$

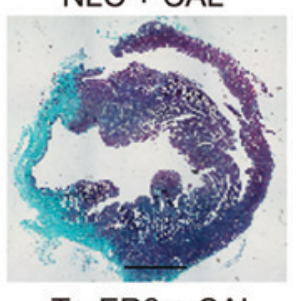

$\mathrm{Tg}-\mathrm{ER} \beta$

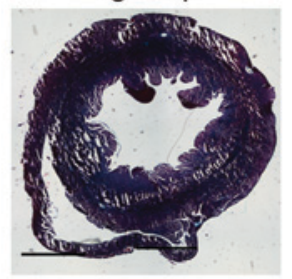

$\mathrm{Tg}-\mathrm{ER} \beta+\mathrm{CAL}$

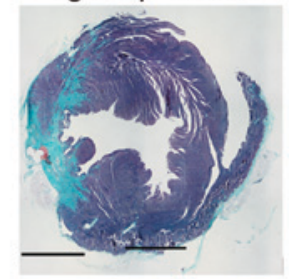

B

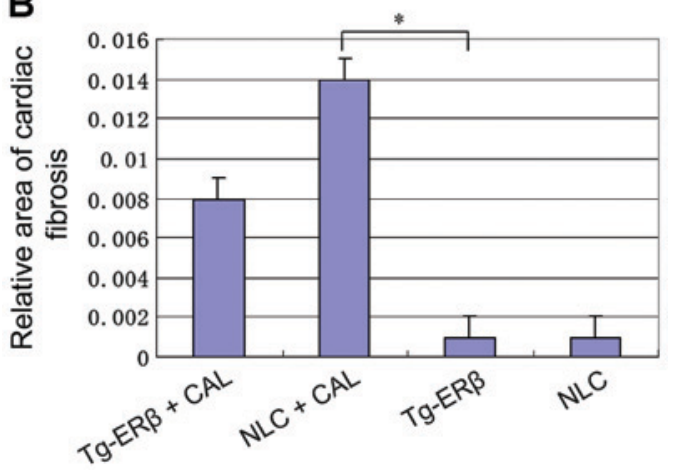

Figure 3. Masson staining of paraffin sections was performed on NLC, $\mathrm{NLC}+\mathrm{CAL}, \mathrm{Tg}-\mathrm{ER} \beta, \mathrm{Tg}-\mathrm{ER} \beta+\mathrm{CAL}$, respectively (myocardial interstitium x100 magnification, perivascular x200 magnification). Image-Pro6.0 software was used to analyze the cardiac fibrosis area quantitatively and statistical results were obtained. Compared with the NLC + CAL group, the area of coronary artery and myocardial interstitial fibrosis was significantly reduced in the Tg-ER $\beta+C A L$ group, and the difference was statistically significant, ${ }^{*} \mathrm{P}<0.05$. ER $\beta$, estrogen receptor $\beta$; NLC, non-transgenic littermate control; CAL, coronary artery ligation. 
A

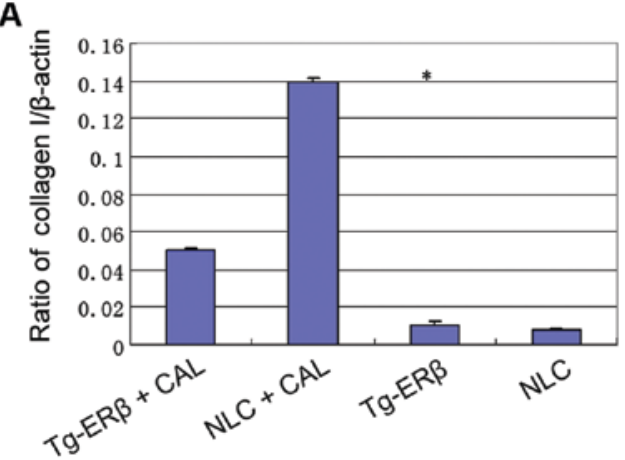

B

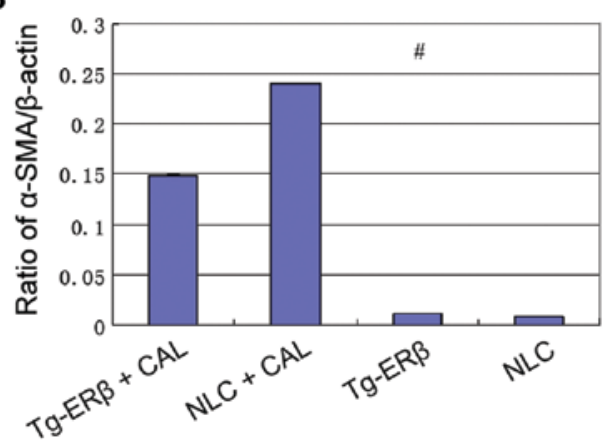

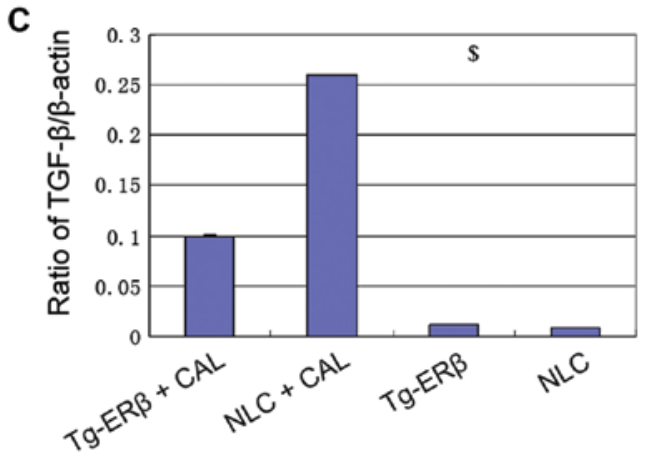

Figure 4. RT-PCR detection of the expression of collagen I, TGF- $\beta, \alpha$-SMA. (A) At 7 days after cardiac infarction, the expression levels of collagen I were significantly increased, but the increased level of NLC mice was significantly higher than that of Tg-ER $\beta$ mice, and the difference was statistically significant, ${ }^{*} \mathrm{P}<0.05$. (B) At 7 days after cardiac infarction, the expression levels of $\alpha$-SMA in heart tissue were significantly increased, but the increased level of NLC mice was significantly higher than that of Tg-ER $\beta$ mice, and the difference was statistically significant, ${ }^{\#} \mathrm{P}<0.05$. (C) At 7 days after cardiac infarction, the expression levels of TGF- $\beta$ in heart tissue were significantly increased, but the increased level of NLC mice was significantly higher than that of Tg-ER $\beta$ mice, and the difference was statistically significant, ${ }^{\$} \mathrm{P}<0.05$. ER $\beta$, estrogen receptor $\beta$; NLC, non-transgenic littermate control; CAL, coronary artery ligation.

weight and body weight of each group, and calculated the ratio of heart weight to body weight $(\mathrm{HW} / \mathrm{BW})$. We found that the average $\mathrm{HW} / \mathrm{BW}$ of $\mathrm{Tg}-\mathrm{ER} \beta+$ AngII group was significantly increased $(\mathrm{P}<0.05)$ compared with the NLC group (Fig. 2).

Masson staining was used to compare the collagen deposition in the heart of mice. After Masson staining, the mouse myocardial interstitial and perivascular appeared as blue collagen fiber, compared with Tg-ER $\beta+$ CAL group, heart coronary artery and myocardial fibrosis area of NLC + CAL mice significantly increased $(\mathrm{P}<0.05)$ (Fig. 3).

Collagen I, $\alpha$-SMA, and TGF- $\beta$ expression level of cardiac tissue. RT-PCR was employed to assess the expression level of collagen I, $\alpha$-SMA, TGF- $\beta$ in the hearts of mice. We found that, after ligation of coronary artery, the levels of expression of collagen I, $\alpha$-SMA and TGF- $\beta$ in NLC and Tg-ER $\beta$ mice were significantly increased $(\mathrm{P}<0.05)$. However, the level of increased of collagen I, $\alpha$-SMA, TGF- $\beta$ in NLC mice was significantly higher than in Tg-ER $\beta$ mice $(\mathrm{P}<0.05)$ (Fig. 4).

\section{Discussion}

MI is a common cardiovascular disease. The target organ damage caused by MI is one of the main causes of morbidity and mortality in patients with cardiovascular and cerebrovascular events (1). MI induced heart remodeling occurs after MI, cardiac or vascular anatomical structure and morphology changes adaptively caused by hemodynamic, neurohumoral, endocrine and metabolic abnormalities. In the heart, the ventricular wall becomes thin, the heart cavity increases, inflammatory cells and infiltration of inflammatory factors appear in the myocardial tissue of the infarct area, gradually replaced by scar tissue (2-4).

In the extracellular matrix of the heart, $\sim 80 \%$ is type I collagen, collagen is mainly composed of cardiac fibroblasts synthesis and secretion. Its function is regulated by a variety of factors $(17,18)$. TGF- $\beta$ is one of the most important inflammatory factors that adjust fibroblast function. We found that after CAL, TGF- $\beta$ mRNA expression increased significantly, suggesting that TGF- $\beta$ was involved in the fibrosis process after MI. This was consistent with other findings (19). In addition, the ability of collagen synthesis of fibroblasts was also significantly increased (20-22). In the present study, we constructed a mouse model of MI by CAL. At 7 days after MI, echocardiography indicated that compared with the NLC + CAL group, the degree of reduction of end echocardiographic diastolic PWTD and end systolic PWTS was significantly eased in the Tg-ER $\beta$ group. The degree of increase of end systolic LVESD and end echocardiographic diastolic LVEDD was significantly decreased $(\mathrm{P}<0.05)$. In addition, Masson staining showed that after MI, collagen synthesis in NLC mice was significantly increased. By contrast, heart tissue collagen of $\mathrm{Tg}-\mathrm{ER} \beta$ mice was relatively low $(\mathrm{P}<0.05)$, indicating that $\mathrm{ER} \beta$ is helpful to inhibit the process of myocardial fibrosis and remodeling after MI, improving the ability of cardiac anti-fibrosis.

Some studies suggest that the increase in acute MI in postmenopausal women may be related to the decrease of estrogen 
in the body and decrease in the expression of $\operatorname{ER} \beta$ (23). In the present study, after Tg-ER $\beta$ mice + AngII perfusion, the expression levels of collagen I, $\alpha$-SMA, TGF- $\beta$ mRNA were significantly lower in the wild-type mice $(\mathrm{P}<0.05)$. ER can be cloned and proliferated in human vascular endothelial cells after the liquid shear stress is induced (24). The shear stress on the target is a strong inducer. Expression of nitric oxide (NO) synthase can be promoted (25). This suggests that estrogen may play a role through the L-arginine/NO pathway (26). Many laboratories have demonstrated that non-endothelium-dependent vascular relaxation ER mediates will not occur after L-NAME treatment with endothelial or NO synthase inhibitors (26). Some recent studies have further gained understanding of the function of vascular endothelial cells mediated by GPER $(27,28)$. In cerebral vascular disease and acute kidney injury, both in male and female, the protective effect of estrogen is regulated by GPER $(29,30)$ and plays a protective function. Collectively, cardiac remodeling and cardiac fibrosis after MI is a complex regulation of various inflammatory factors. In the present study, in vivo experiments confirmed Tg-ER $\beta$ has a protective effect on cardiac remodeling after MI. However, the specific mechanisms of myocardial protection of $\mathrm{ER} \beta$ need to be further explored.

\section{References}

1. Lee KH, Jeong MH, Ahn Y, Cho MC, Kim CJ and Kim YJ: New horizons of acute myocardial infarction: From the Korea Acute Myocardial Infarction Registry. J Korean Med Sci 28: 173-180, 2013.

2. Gerber Y, Weston SA, Jiang R and Roger VL: The changing epidemiology of myocardial infarction in Olmsted County, Minnesota, 1995-2012. Am J Med 128: 144-151, 2015.

3. Kirchberger I, Wolf K, Heier M, Kuch B, von Scheidt W, Peters A and Meisinger $\mathrm{C}$ : Are daylight saving time transitions associated with changes in myocardial infarction incidence? Results from the German MONICA/KORA Myocardial Infarction Registry. BMC Public Health 15: 778, 2015.

4. Shah AS, Griffiths M, Lee KK, McAllister DA, Hunter AL, Ferry AV, Cruikshank A, Reid A, Stoddart M, Strachan F, et al: High sensitivity cardiac troponin and the under-diagnosis of myocardial infarction in women: Prospective cohort study. BMJ 350: g7873, 2015.

5. Kirchberger I, Meisinger C, Golüke H, Heier M, Kuch B, Peters A, Quinones PA, von Scheidt W and Mielck A: Long-term survival among older patients with myocardial infarction differs by educational level: Results from the MONICA/KORA myocardial infarction registry. Int J Equity Health 13: 19, 2014.

6. Stillman AE, Oudkerk M, Bluemke D, Bremerich J, Esteves FP, Garcia EV, Gutberlet M, Hundley WG, Jerosch-Herold M, Kuijpers D, et al; North American Society of Cardiovascular Imaging; European Society of Cardiac Radiology: Assessment of acute myocardial infarction: Current status and recommendations from the North American society for Cardiovascular Imaging and the European Society of Cardiac Radiology. Int J Cardiovasc Imaging 27: 7-24, 2011.

7. Sim DS, Jeong MH, Ahn Y, Kim YJ, Chae SC, Hong TJ, Seong IW, Chae JK, Kim CJ, Cho MC, et al; Korea Acute Myocardial Infarction Registry (KAMIR) Investigators: Effectiveness of drug-eluting stents versus bare-metal stents in large coronary arteries in patients with acute myocardial infarction. J Korean Med Sci 26: 521-527, 2011.

8. Cho JS, Youn HJ, Her SH, Park MW, Kim CJ, Park GM, Jeong MH, Cho JY, Ahn Y, Kim KH, et al; Korea Acute Myocardial Infarction Registry Investigators: The prognostic value of the left ventricular ejection fraction is dependent upon the severity of mitral regurgitation in patients with acute myocardial infarction. J Korean Med Sci 30: 903-910, 2015.

9. Omoto $\mathrm{Y}$ and Iwase $\mathrm{H}$ : Clinical significance of estrogen receptor $\beta$ in breast and prostate cancer from biological aspects. Cancer Sci 106: 337-343, 2015.
10. Pastore MB, Jobe SO, Ramadoss J and Magness RR: Estrogen receptor- $\alpha$ and estrogen receptor- $\beta$ in the uterine vascular endothelium during pregnancy: Functional implications for regulating uterine blood flow. Semin Reprod Med 30: 46-61, 2012.

11. Mufudza C, Sorofa W and Chiyaka ET: Assessing the effects of estrogen on the dynamics of breast cancer. Comput Math Methods Med 2012: 473572, 2012.

12. Crooke PS, Justenhoven C, Brauch H, Dawling S, Roodi N, Higginbotham KS, Plummer WD, Schuyler PA, Sanders ME, Page DL, et al; GENICA Consortium: Estrogen metabolism and exposure in a genotypic-phenotypic model for breast cancer risk prediction. Cancer Epidemiol Biomarkers Prev 20: 1502-1515, 2011.

13. Cardaci S and Ciriolo MR: TCA cycle defects and cancer: When metabolism tunes redox state. Int J Cell Biol 2012: 161837, 2012.

14. Colditz GA: Relationship between estrogen levels, use of hormone replacement therapy, and breast cancer. J Natl Cancer Inst 90: 814-823, 1998.

15. Wang M, Wang Y, Weil B, Abarbanell A, Herrmann J, Tan J, Kelly $\mathrm{M}$ and Meldrum DR: Estrogen receptor beta mediates increased activation of PI3K/Akt signaling and improved myocardial function in female hearts following acute ischemia. Am J Physiol Regul Integr Comp Physiol 296: R972-R978, 2009.

16. Pedram A, Razandi M, O'Mahony F, Lubahn D and Levin ER: Estrogen receptor-beta prevents cardiac fibrosis. Mol Endocrinol 24: 2152-2165, 2010.

17. Vornehm ND, Wang M, Abarbanell A, Herrmann J, Weil B, Tan J, Wang Y, Kelly M and Meldrum DR: Acute postischemic treatment with estrogen receptor-alpha agonist or estrogen receptor-beta agonist improves myocardial recovery. Surgery 146: 145-154, 2009.

18. Bashey RI, Donnelly M, Insinga F and Jimenez SA: Growth properties and biochemical characterization of collagens synthesized by adult rat heart fibroblasts in culture. J Mol Cell Cardiol 24: 691-700, 1992.

19. Carver W, Nagpal ML, Nachtigal M, Borg TK and Terracio L: Collagen expression in mechanically stimulated cardiac fibroblasts. Circ Res 69: 116-122, 1991.

20. Zhang W, Chancey AL, Tzeng HP, Zhou Z, Lavine KJ, Gao F, Sivasubramanian N, Barger PM and Mann DL: The development of myocardial fibrosis in transgenic mice with targeted overexpression of tumor necrosis factor requires mast cell-fibroblast interactions. Circulation 124: 2106-2116, 2011.

21. Duerrschmid C, Crawford JR, Reineke E, Taffet GE, Trial J, Entman ML and Haudek SB: TNF receptor 1 signaling is critically involved in mediating angiotensin-II-induced cardiac fibrosis. J Mol Cell Cardiol 57: 59-67, 2013.

22. Weber KT, Sun Y, Bhattacharya SK, Ahokas RA and Gerling IC: Myofibroblast-mediated mechanisms of pathological remodelling of the heart. Nat Rev Cardiol 10: 15-26, 2013.

23. Burns KA, Li Y, Arao Y, Petrovich RM and Korach KS: Selective mutations in estrogen receptor alpha D-domain alters nuclear translocation and non-estrogen response element gene regulatory mechanisms. J Biol Chem 286: 12640-12649, 2011.

24. Prossnitz ER and Barton M: The G-protein-coupled estrogen receptor GPER in health and disease. Nat Rev Endocrinol 7: 715-726, 2011.

25. Fleming I: Molecular mechanisms underlying the activation of eNOS. Pflugers Arch 459: 793-806, 2010.

26. Meyer MR, Prossnitz ER and Barton M: The G protein-coupled estrogen receptor GPER/GPR30 as a regulator of cardiovascular function. Vascul Pharmacol 55: 17-25, 2011.

27. Gros R, Ding Q, Liu B, Chorazyczewski J and Feldman RD: Aldosterone mediates its rapid effects in vascular endothelial cells through GPER activation. Am J Physiol Cell Physiol 304: C532-C540, 2013.

28. Ding Q, Hussain Y, Chorazyczewski J, Gros R and Feldman RD: GPER-Independent effects of estrogen in rat aortic vascular endothelial cells. Mol Cell Endocrinol 399: 60-68, 2015.

29. Hutchens MP, Fujiyoshi T, Komers R, Herson PS and Anderson S: Estrogen protects renal endothelial barrier function from ischemia-reperfusion in vitro and in vivo. Am J Physiol Renal Physiol 303: F377-F385, 2012.

30. Murata T, Dietrich HH, Xiang $\mathrm{C}$ and Dacey RG Jr: $\mathrm{G}$ protein-coupled estrogen receptor agonist improves cerebral microvascular function after hypoxia/reoxygenation injury in male and female rats. Stroke 44: 779-785, 2013. 